\title{
Sexual Risk-Taking Behavior: The Role of Religiosity among Poor Brazilian Youth*
}

\section{La conducta riesgoza de la sexualidad: el rol de la religiosidad entre la juventud de escazos recursos en Brazil}

Received: 14 October 2015 | Accepted: 15 July 2016

\author{
Elder Cerqueira-Santos** \\ Federal University of Sergipe, Brazil \\ Sílvia Koller
}

Federal University of Rio Grande du Sol, Brazil

**Correo electrónico: eldercerqueira@gmail.com

\begin{abstract}
The aim of this study is to investigate the role of religiosity and religious affiliation on sexual risk among young people living in poor social conditions in Brazil. In addition, we investigate if religiosity plays a protective role in young people's sexual life, with specific regard to delay of first intercourse, condom use, and contraception. This is a cross-sectional study with 7572 participants, 14-24 years old, from seven states of Brazil, who answered a self-administered questionnaire with 109 questions in the school environment. We found an association between religiosity and lower odds of sexual debut. The group that have had already initiated sexual intercourse was not different on the sexual risk behavior. Young people of low socioeconomic status in Brazil have the sexual behavior slightly influenced by religious norms.
\end{abstract}

Keywords

sexuality, religion, adolescence.

\section{RESUMEN}

El objetivo de este estudio es investigar el papel de la religiosidad y la religiosn en el riesgo sexual entre los jóvenes que viven en Condiciones de pobreza en Brasil. Además, investigamos si la religiosidad juega un papel Papel protector en la vida sexual de los jóvenes, con especial Retraso de la primera relación sexual, uso del condón y anticoncepción. Esto es un Estudio transversal con 7572 participantes, 14-24 años de edad, de siete estados de Brasil, que respondieron a un cuestionario autoadministrado con 109 Preguntas en el ambiente escolar. Encontramos una asociación entre Religiosidad y menores probabilidades de debut sexual. El grupo que ha tenido. Las relaciones sexuales ya iniciadas, no eran diferentes en el riesgo sexual. Los jóvenes de bajo nivel socioeconómico en Brasil tienen Comportamiento sexual ligeramente influenciado por las normas religiosas.

Palabras clave

sexualidad, religión, adolescencia.

How to cite: Cerqueira-Santos, E., \& Koller, S. (2016). Sexual Risk-Taking Behavior: The Role of Religiosity among Poor Brazilian Youth. Universitas Psychologica, 15 (4). http://dx.doi.org/10.11144/Javeriana.upsy15-4.srbr 
Sexual risk-taking behavior has been a widely discussed topic in public health, especially in developing countries, as Brazil, where the SDTs rates are higher than in the USA and Europe (Brown, Jejeebhoy, Shah, \& Yount, 2001). Among adolescents and young population this issue has a stronger harmful condition, once they are vulnerable to a double consequence: STDs and an early pregnancy. According to many studies, early sexual experience is associated with increased health risk (Rostosky, Regnerus,

\& Wright, 2003). Moreover, the age of coital debut has some variation by other variables, such as gender, race, religion, and social class.

In a 2004 survey, Barbosa Junior, Szwarcwald, Pascom and Souza Júnior (2004) reported that the Brazilian youth were having their first sexual intercourse earlier than in former studies and, moreover, that those who were sexually active were having a larger number of partners. According to the Brazilian Health Ministry (2010), 36\% of the persons between

15 and 24 years old had their first intercourse before they were 15 years old. On the other hand, only $21 \%$ of the sample aged $25-29$, during the collection data time, had their debut before 15 . The authors point out that $20 \%$ of the sample already had more than ten sexual partners in their lives, and $7 \%$ had have more than five partners only in the last year. Moreover, data have shown an increase of HIV/AIDS and STDs among Brazilian youth (Oliveira, Dias, \& Silva, 2005). Additionally, studies estimate that $20-25 \%$ of pregnant Brazilian women are adolescents (Cerqueira-Santos, Paludo, Diniz, \& Koller, 2010).

Religiosity and sexuality are closely linked to each other, as mentioned by Lefkowitz, Gillen, Shearer, and Boone (2004). In general, most studies have shown that religion plays as a protective factor against sexual risk-taking behavior (Whitehead, Wilcox, \& Rostosky, 2001). Religion appears in these studies to be a protective factor leading to delay in first intercourse and to safer sexual behaviors such as monogamy, condom use, and contraception use (Doswell, Kouyate, \& Taylor, 2003; Whitehead, 2001).
The objective of this study is to investigate the role of religiosity and religious affiliation on sexual risk among young people living in poor social conditions in Brazil. In addition, we investigate if the religiosity plays a protective role in young people's sexual life, with specific regard to delay of first intercourse, condom use, and contraception.

\section{Sexual Risk-Taking Behavior}

The definition of sexual risk behavior has been polemical in the scientific literature and has included variables such as age, number of sexual partners, and protective methods (condom and contraception). According to $\mathrm{Li}$ and colleagues (2000), sexual risk behavior involves the unprotected sexual intercourse and number of partners. Xavier (2005), in an extensive review, discussed this definition and found that most international studies use only the condom use as an indicator of protected sex.

HIV/AIDS data from Brazil indicate an increased risk of infection in specific groups, such as women, youths, and those with low socio-economic status (Brazilian Health Ministry, 2010). Among HIV-infected Brazilian women, for instance, most were sexually infected by their stable male partner (Paiva et al.,

2003). Additionally, only $14.5 \%$ of people use condoms at first sexual intercourse consistently. Among sexually active 14-to-25 years old, the percentage who use condoms consistently is higher, but not ideal (28.3\%) (Paiva et al., 2003). In 2010, the Brazilian Health Ministry reported that there were 27,000 HIV-infected patients under 24 years old (Brazilian Ministry of Health, 2010).

Besides sexually transmitted infections (STI), pregnancy can also be an undesired consequence of unprotected sex. According to the Brazilian Annual Health Report (2010), about 23\% of the births in the country were from a young mother, aged between 15 and 19 years old. In addition to the public health impact, early pregnancy frequently causes changes in the familiar dynamic and social life of the adolescent. 
Moreover, undesired pregnancy increases the episodes of abortion (Pereira et al., 2000), which is illegal in Brazil, driving adolescents to dangerous and clandestine procedures and increasing their risk of complications.

\section{Religiosity and Sexuality}

Our main hypothesis is that more religious individuals are more likely to delay the first sexual intercourse. Moreover, as Bearman and Bruckner (1999) indicated, some differences can be found between different religious affiliations. The authors found that American Catholics and fundamentalist Protestants were less likely to be sexually active than members of other religious groups. On the other hand, some studies confirmed the hypothesis that church attendance is a more powerful predictor of early sexual intercourse without regard to specific affiliation (Crockett, Bingham, Chopak \& Vicary, 1996; Lefkowitz, Gillen, Shearer \& Boone, 2004).

Young people can develop self-regulation mechanisms associated with spirituality and can avoid risky situations, such as sexual "temptation" or group influence (Doswell et al., 2003). Whitehead (2001) argued that religious associations have a protective role during adolescence by reducing the risk exposure and leading adolescents to make healthier choices, such as abstinence. Whitehead (2001) analyzing a pro-abstinence religious program, found out that, despite a higher rate of abstinent youths in a religious group, the same young people were using condoms and contraceptives less in their first sexual intercourse.

The relationship between religiosity and sexuality has to be viewed as a two-way street (Hardy \& Raffaelli, 2003). In this bidirectional association, religion also serves as a force of social control that provides negative consequences for sexual behavior. "For individuals deal with the cognitive dissonance, they must either change their behaviors or their thoughts that are in opposition" (p. 732); with this statement, Hardy and Raffaelli also suggest the possibility of teens to keep their sexual behavior and change some religious ideals. This has been revealed in some US studies (Wilcox, Rostosky, Randal, \& Wright, 2001), but still little research has been done in this area in Brazil.

\section{Religiosity}

In this study we considered both religion affiliation and religiosity. The measure of religiosity has been criticized by the literature as simplistic, accessing only one dimension of religiosity, as attendance or faith. In this study we use a multidimensional short seven-item scale to measure religious identity, behavior, perception, and practice and also asked two additional questions about religious affiliation.

This study has an ecological approach (Bronfenbrenner, 1996/1979), using social control theories (Hirschi, Travis \& Gottfredson, 1995). According to those theories, it is important to observe how human behavior is regulated in the main social model. Considering the social model as a rule, many institutions work towards an adaptation of the model (school, family, church, etc.). In this way, the more involved a person is with those institutions, the more conventional is his/her behavior. As investigated in other studies (Hardy \& Raffaelli,

2003), the main idea of those theories are that "although teen have a tendency towards sexual involvement, if they are bonded to a social organization with conservative norms regarding sexual behavior, they should be motivated to delay sexual behavior" (p.732).

In this study we investigate the association between religiosity and sexual behavior in a sample of poor Brazilian youth. Based on previous empirical studies, we predicted finding similar results for a Brazilian sample:

Individuals with higher level of religiosity are more likely to be sexually abstinent, delaying first sexual intercourse through beliefs about negative outcomes of sex, so that more religious people will have a higher mean age for sexual debut.

1. Between sexually active individuals, those who are more religious have a less 
protective behavior, such as condom use and contraceptive methods use, if they follow the religious prescriptions about their sexual life.

2. On the other hand, we expect to find higher sexual risk exposure among religious people or people with a higher level of religiosity.

3. Based on the huge gender difference for sexual roles in the Brazilian "machista" culture, we expect to find an effect of gender for the influence of religiosity on sexual behavior.

\section{Method}

\section{Participants}

This study was conducted in schools in impoverished neighborhoods and nongovernmental organizations of six Brazilian cities. The sample consisted of 7572 adolescents and young adults; for the current analysis, we focused on the respondents aged 14-24 (see demographic information in the results section).

Using data from the 2000 Brazilian census (Instituto Brasileiro de Geografia e Estatística, 2003), each of the neighborhoods of the city was characterized based on five indicators: (1) salary of the head of household; (2) educational level of the head of household; (3) construction material of family home; (4) whether the house has running water; (5) whether the house has indoor plumbing. Neighborhoods in the bottom ten percent on two or more indicators were identified. With this list of low-income neighborhoods, ten of them were randomly chosen in each city. Lists of municipal and state public schools were obtained from the state and city Departments of Education and one school from each neighborhood was randomly selected for recruitment. Each of the ten schools was visited by study personnel who described the research goals and discussed data collection procedures. Brazilian public schools offer three sessions (morning, afternoon, evening) that are attended by different groups of students, and data collection activities were distributed across the various sessions. The out-of-school sample was recruited through institutions identified by school personnel within the selected neighborhoods, and through contacts established during the research team's prior work with homeless youths.

\section{Procedures}

Youths completed the questionnaire in groups during two-hour sessions supervised by trained graduate and undergraduate research assistants. The consent form was read aloud to inform youth about the purpose of the study, confidentiality procedures, and the availability of psychological services. The researchers then provided instructions on completing the questionnaire. Youths filled out the questionnaire individually; research assistants helped youths with physical disabilities or reading difficulties to complete the measures.

\section{Measures}

Respondents completed a 109-question instrument about five main domains in their lives. For this study we explored two domains: sexuality and religiosity. In addition, demographic data were collected.

\section{Sexuality}

This domain was assessed by asking participants about their sexual experiences in their entire lives. We asked about sexual orientation, sexual debut, age at first sexual intercourse, condom use (frequency), contraception methods, STI prevention, pregnancy, and sexual abuse. Based on the items and literature review (Rafaelli \& Crockett, 2003), we created a score of risk- taking behavior composed of the three following items: non-use of condoms (two items - as contraception and for preventing STIs); early pregnancy (became pregnant before 14 years 
old), and abortion (natural and forced). One point was assigned for each item.

\section{Religiosity}

The dimension "Religiosity/Spirituality" was measured by a seven-item scale (five point Likert-type scale for each item) created for the Brazilian sample: Religion/spirituality has been important for my life; I usually go to religious meetings; I usually read religious scriptures or pray during the day; I usually give thanks to God for things happening in my life; I ask God to help me solve my problems; I usually read religious scriptures or pray when $\mathrm{I}$ am in a difficult situation; I look for help from my religious institution (church, temple etc.) when I am in a difficult situation.

Factor analyses confirmed the use of the items as one factor $(\mathrm{KMO}=0,86)$ with a explained variance of $57 \%$. Reliability for this sample was considered appropriate (Cronbach's alpha $=0.87$ ). The sample was divided in three groups according to the level of religiosity: low, medium, and high (Cerqueira-Santos, et al., 2010).

\section{Results}

\section{Descriptive Analyses}

The sample was composed of 7572 adolescents residents in the Brazilian states of Pernambuco, Rio Grande do Sul, Amazonas, Minas Gerais, São Paulo, Mato Grosso do Sul, and Distrito Federal. The mean age was 16.5 years (SD 1.82), ranging from 14 to 24 years. $45 \%$ of participants were male. For the total sample $58 \%$ reported average monthly income of less than minimum wage, and $69 \%$ used community health services. 97\% reported being heterosexual, $46 \%$ already had sexual intercourse, and the mean age for the sexual debut for these was 14.4 (DP 1.89). Only $54 \%$ reported condom use and $12 \%$ had been pregnant or impregnated a partner. The sexual risk score $(\mathrm{M}=0.60, \mathrm{SD}=0.6)$ ranged from 0 (had never had sex) to 4 (participants who reported 4 risk situations). No participants reported 5 or 6 risk exposures. For religious affiliation, 50\% were Catholic, $23 \%$ Protestant and $19 \%$ believed in God but did not have a religious affiliation (See Table 1).

\section{Table 1}

Socio-demographic Sample's Characteristics

\begin{tabular}{|c|c|c|}
\hline \multicolumn{3}{|l|}{ Characteristics } \\
\hline Mean Age (SD) & & 16.5 years $(1.82)$ \\
\hline \multirow{2}{*}{$\operatorname{Sex}(\%)$} & Men & 45.3 \\
\hline & Women & 54.7 \\
\hline \multicolumn{2}{|l|}{ Marital Status (\%) } & 93.5 single \\
\hline \multirow{7}{*}{ State of Residency (\%) } & Rio Grande do Sul & 13 \\
\hline & São Paulo & 30 \\
\hline & Pernambuco & 15 \\
\hline & Mato Grosso do Sul & 13 \\
\hline & Amazonas & 3 \\
\hline & Distrito Federal & 11 \\
\hline & Minas Gerais & 12 \\
\hline \multirow{2}{*}{$\begin{array}{l}\text { Mean monthly wage } \\
(\%)\end{array}$} & Less than a minimum wage & 47.7 \\
\hline & More than a minimum wage & 52.3 \\
\hline \multirow{3}{*}{$\begin{array}{l}\text { Community } \\
\text { Service (\%) }\end{array}$} & Yes & 68.7 \\
\hline & No & 28.7 \\
\hline & Do not have & 2.6 \\
\hline \multirow{2}{*}{\multicolumn{2}{|c|}{$\begin{array}{l}\text { Sexual relation (\%) } \\
\text { Mean age of debut (SD) }\end{array}$}} & $46.1 \%$ \\
\hline & & 14.4 years $(1.89)$ \\
\hline \multirow{2}{*}{ Sexual orientation (\%) } & Heterosexual & 97.4 \\
\hline & No heterosexual & 2.6 \\
\hline \multicolumn{2}{|l|}{ Pregnancy (\%) } & 11.8 \\
\hline \multirow{2}{*}{ Use of condom (\%) } & Consistent & 54.3 \\
\hline & Inconsistent & 45.7 \\
\hline \multirow{5}{*}{ Religion (\%) } & Catholics & 50 \\
\hline & Protestants/Evangelic & 23 \\
\hline & Do believe in God/No religion & 19 \\
\hline & Do not believe in God & 1.8 \\
\hline & Others & 6.2 \\
\hline
\end{tabular}

Source: own work

Table 2 presents data comparing groups that had and had not had their sexual debuts. The groups formed by male, older participants, less religious, and homosexuals differ significantly with the highest percentage for first sexual intercourse than their peers. There was no significant difference for the groups by income and use of health center. 
Table 2

Sample's Characteristics for Sexual Debut

\begin{tabular}{|c|c|c|c|c|}
\hline \multirow{2}{*}{ Characteristics } & & \multicolumn{3}{|c|}{ Sexual Debut } \\
\hline & & Total & Yes $f(\%)$ & $P$ \\
\hline \multirow{2}{*}{ Sex } & Male & 3178 & $1855(58.4 \%)$ & \multirow[t]{2}{*}{$<0.001$} \\
\hline & Female & 3856 & $1384(35.9 \%)$ & \\
\hline \multirow{2}{*}{ Age group } & Adolescent & 6434 & $2754(42.8 \%)$ & \multirow[t]{2}{*}{$<0.00$} \\
\hline & Young & 607 & $489(80.6 \%)$ & \\
\hline \multirow{2}{*}{ Income } & Less than minimum & 3207 & $1491(46.5 \%)$ & \multirow[t]{2}{*}{$=0.85$} \\
\hline & More than minimum & 3519 & $1644(46.7 \%)$ & \\
\hline \multirow{3}{*}{$\begin{array}{l}\text { Community Health } \\
\text { Service }\end{array}$} & Yes & 4506 & $2067(45.9 \%)$ & \multirow{3}{*}{$=0.346$} \\
\hline & No & 1897 & $835(44.0 \%)$ & \\
\hline & Not available & 169 & $80(47.3 \%)$ & \\
\hline \multirow{2}{*}{ Sexual Orientation } & Heterosexual & 6304 & $2908(46.1 \%)$ & \multirow[t]{2}{*}{$<0.001$} \\
\hline & Non-heterosexual & 162 & $97(59.9 \%)$ & \\
\hline \multirow{3}{*}{ Religiosity } & Low & 1966 & $1068(54.3 \%)$ & \multirow[t]{3}{*}{$<0.001$} \\
\hline & Medium & 2124 & $932(43.9 \%)$ & \\
\hline & High & 1669 & $561(33.6 \%)$ & \\
\hline
\end{tabular}

Source: own work

\section{Sexual Risk Behavior}

For the sub sample formed by participants with sexual debut, a composite was calculated for sexual risk behavior based on three specific variables: condom use, pregnancy, and abortion episode. Table 3 shows the differences for the composite of sexual risk behavior and for specific sexual behaviors. A significant difference was found in sexual risk behavior with higher proportions of males, younger participants, those earning less than minimum wage, and users of the community health service having higher risk behaviors. Sexual orientation, religiosity, and religious affiliation showed no significant difference in the composite of sexual risk behavior.

For condom use, significant differences were found with higher rates of condom use for males and adolescents. Regarding episodes of pregnancy, a significant difference was found with the highest percentage for women's groups, youths, poor, and users of the community health service. Only the women's group had a significant difference with respect to abortions.
Table 3

Sample's Characteristics for Sexual Risk Taking Behavior

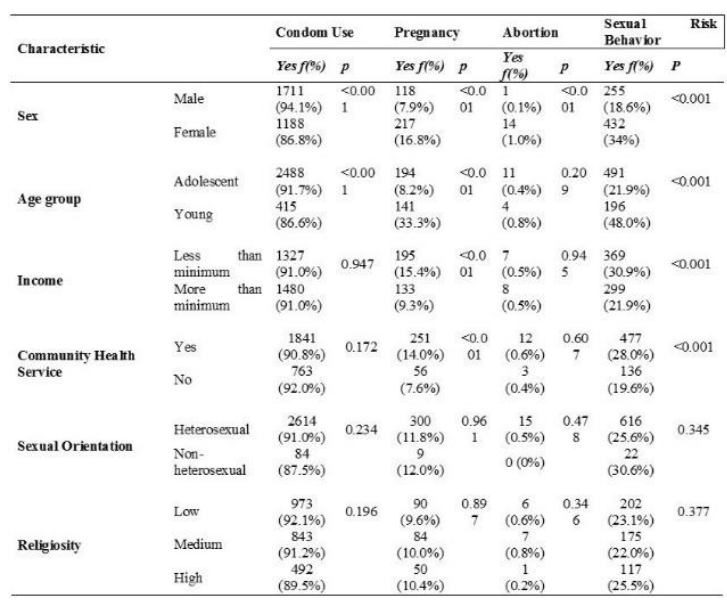

Note: *67 participantes relataram não ter posto de saúde na comunidade. Source: own work

Religiosity did not play a significant role for sexual risk behavior, besides the significance for sexual debut. Moreover, participants in the high level group of religiosity showed higher levels of sexual risk behavior and lower level of condom use.

Table 4 presents a logistic regression for sexual risk taking behavior. The explained variance of the final model was $10.6 \%$. The final model showed a result with significance for sex, age, and income as predictors for sexual risk-taking behavior. Being female, younger, and low income group are the stronger predictive variables for the sexual risk behavior.

\section{Table 4}

Regression Analyses for Risk Sexual Behavior

\begin{tabular}{|c|c|c|c|c|}
\hline \multirow{2}{*}{ Variable } & \multicolumn{3}{|c|}{ Model1 } & \multirow[b]{2}{*}{ IC $(95 \%)$} \\
\hline & B & SE B & $\operatorname{Exp}(\mathrm{b})$ & \\
\hline Sex & $-0.830^{* *}$ & 0.120 & 0.436 & $0.345-0.552$ \\
\hline Age & $-0.229 * *$ & 0.028 & 0.795 & $0.752-0.841$ \\
\hline Community Health Service & 0.108 & 0.116 & 1.114 & $0.887-1.399$ \\
\hline Income & $0.365^{* * *}$ & 0.117 & 1.440 & $1.146-1.810$ \\
\hline Religiosity & 0.052 & 0.076 & 1.053 & $0.907-1.222$ \\
\hline Sexual Orientation & 0.059 & 0.359 & 1.061 & $0.525-2.145$ \\
\hline Nagelkerke R2 & 0.106 & & & \\
\hline$-2 \log$ & 1863.65 & & & \\
\hline
\end{tabular}

Note: Para a variável sexo o valor maior representa feminino, para orientação sexual maior valor representa não-heterossexual, para uso da UBS maior valor representa mais uso. **p<0,001 Source: own work 


\section{Discussion}

The mean age for the first sexual intercourse was lower than expected for the Brazilian population, which is 16 years old (Ministry of Health, 2010). This finding is accurate with the prediction of lowering the age for first sexual intercourse and confirms the trend indicated by other studies (Barbosa Junior et al., 2004).

A high number of adolescents and young people without religion can be seen, confirming the idea that at this stage there is a tendency to reduce the institutionalized religions and a religious transit (Almeida \& Montero, 2001). We must consider that, traditionally, the index of selfaffirmation as Catholics is higher, even if that religion is not actually practiced. Part of the explanation for this lies in the fact that religiosity is part of Brazilian culture and became part of the identity constructed for those who were educated in traditional Catholic families, since they are baptized and initiated into this religion (Almeida \& Montero, 2001).

Religiosity appears to be a factor delaying the sexual debut, but for the composite sexual risk behavior, religiosity presents no significant influence. As pointed out by Cerqueira-Santos (2008), religiosity may be a protective factor in regards to the chance of postponing first sexual intercourse, however, after the sexual debut, adolescent and youths tend to behave similarly in terms of sexual risk exposures.

As expected, age and sex are variables associated with risk behavior. We must consider that the answers given by men and women may have a difference with respect to the kind of behavior, despite the questions being directed to both sexes. Men may have responded more spontaneously about condom use and women about pregnancy and abortion, reaffirming the cultural difference in how boys and girls deal with their sexual life (Antunes, Peres, Paiva, Stall $\&$ Hearst, 2002).

The association between income and risk is mainly related to episodes of pregnancy for the lower income group, corroborating the WHO statistics (2005) and the Ministry of Health (2005), as well as the hypothesis presented by
Waystaff, Delameth, and Havens (1999) that the impoverished population is more vulnerable to risky sexual behaviors. Likewise, the use of community health center correlates the risk with higher frequency for the group that went through an episode of pregnancy.

A logistic regression showed that only sex, age, and income are significant in the final model for risk behaviors. Overall, data suggest that young people of low socioeconomic status in Brazil have the sexual behavior slightly influenced by religious norms. This finding is consistent with part of the scientific literature in Brazilian religiosity, which points to a trend of youths being away from religious values (Queiroz, 1996). In the dissonance caused between the expression of sexuality and religious recommendations, it appears that the subordination of religious morality has been most common among these youths.

According to Almeida and Montero (2001), the way the religion is lived in Brazil, especially for the Catholic majority, makes the relationship between religion and private life more flexible. Thus, religious experience does not necessarily imply to follow behaviors norms and rigid rules of behavior, with some exceptions. Moreover, as pointed by Antoniazzi (2003) and Pereira (2003), the detachment from the religious institution provides the formation of a peculiar and individual religiosity/spirituality, as those who believe in God but have no religion. This experience is created as idiosyncrasies, including ideas about sexual behavior and contraception. Thus, Brazil creates an environment favorable to a possible reduction of dissonance between sex and religion, unlike the U.S. where these two issues are quite contradictory (Hardy \& Rafaelli, 2003).

\section{References}

Almeida, R., \& Montero, P. (2001). Trânsito religioso no Brasil. São Paulo em Perspectiva, 15 (3), 92-101.

Antunes, M.C., Peres, C.A., Paiva, V., \& Stall R., Hearst, N. (2002) Diferenças na prevenção 
Elder Cerqueira-Santos, Sílvia Koller.

da Aids entre homens e mulheres jovens de escolas públicas em São Paulo, SP. Rev Saúde Pública, 36 (4), 88-95.

Antoniazzi, A. (2003). As religiões no Brasil segundo o censo de 2000. Revista de Estudos da Religião, 2(3), 75-80. Retrieved from http://www.pucsp.br/rever/rv2_2003/ p_antoni.pdf

Barbosa Junior, A., Szwarcwald, C. L., Pascom, A. R. P., \& Souza Júnior, P. B. (2009). Tendências da epidemia de AIDS entre subgrupos sob maior risco no Brasil, 1980-2004. Cadernos de Saúde Pública, 25 (4), 727-737. https://dx.doi.org/10.1590/S0 102-311X2009000400003

Bearman, P. S., \& Brückner, H. (1999). Peer Effects on Adolescent Girls'Sexual Debut and Pregnancy. Washington, D.C.: National Campaign to Prevent Teen Pregnancy.

Brazilian Health Ministry (2010). Prevalências $e$ frequências relativas de doenças sexualmente transmissiveis (DST) em populações selecionadas de seis capitais brasileiras . Brasília: Ministério da Saúde. (Série G. Estatística e Informação em Saúde).

Bronfenbrenner, U. (1996). A ecologia do desenvolvimento humano: Experimentos naturais e planejados. Porto Alegre: Artes Me\#dicas. (Originalmente publicado em 1979).

Brown, A., Jejeebhoy, J., Shah, I., \& Yount, K. (2001). Sexual relations among youth in developing countries: Evidence from WHO case studies (WHO/RHR/01.8). Geneva: World Health Organization.

Cerqueira-Santos, E. (2008). Comportamento sexual e religiosidade: um estudo com jovens brasileiros . Porto Alegre, RS. Tese de doutorado. Universidade Federal do Rio Grande do Sul, 129 p.

Cerqueira-Santos, E., Paludo, S.S., Dei Schirò, E. D., \& Koller, S. H. (2010). Gravidez na adolescência: análise contextual de risco e proteção. Psicologia em Estudo, 15 (1), 72-85. https://dx.doi.org/10.1590/S1413-7 3722010000100009
Crockett, L. J., Bingham, C. R., Chopak, J. S., \& Vicary, J. R. (1996). Timing of first sexual inter-course: The role of social control, social learning, and problem behavior. Journal of Youth and Adolescence, 25, 89111.

Doswell, W. M., Kouyate, M., \& Taylor, J. (2003). The role of spirituality in preventing early sexual behavior. American Journal of Health Studies, 18 (4), 195-202.

Hardy, S., \& Raffaelli, M. (2003). Adolescent religiosity and sexuality: An investigation of reciprocal influences. Journal of Adolescence, 26 (6), 731-739.

Hirschi, Travis \& Michael R. Gottfredson. (1995). Control Theory and the LifeCourse Perspective. Studies of Crime and Crime Prevention 4, 131-142.

IBGE (2003). CENSO 2000 . Instituto Brasileiro de Geografia e Estati\#stica. Retrieved from http://www.ibge.gov.br/censo

Lefkowitz, E.S., Gillen, M.M., Shearer, C.L., Boone, T.L. (2004). Religiosity, sexual behaviors, and sexual attitudes during emerging adulthood. $J$ Sex Res., 41(2), 150-9.

Oliveira, S., Dias, M. R., \& Silva, M. (2005). Adolescentes e AIDS: fatores que influenciam a intenção de uso do preservativo. Jornal Brasileiro de Doenças Sexualmente Transmissíveis, 17 (1), 32-38.

Pereira, J. C. (2003). A linguagem do corpo na devoção popular do catolicismo. Revista de Estudos da Religião, 3 , 67-98. Retrieved from http://www.pucsp.br/rever/rv3_2003/ p_pereira.pdf

Queiroz, J. J. (1996). As Religiões e o sagrado nas encruzilhadas da pós-modernidade. In J. J. Queiroz (Ed.), Interfaces do sagrado. Em véspera de um milênio (pp. 25-43). São Paulo: Olho d'água.

Rafaelli, M. \& Crockett, L. J. (2003). Sexual risk taking in adolescence: The role of self-regulation and attraction to risk. Developmental Psychology, 39 (6), 10361046.

Rostosky, S.S, Regnerus, M.D., \& Wright, M.L. (2003). Coital debut: the role of religiosity 
and sex attitudes in the Add Health Survey. J Sex Res., 40(4), 358-67.

Szwarcwald, C. L., Júnior, A. B., Pascom, A. R., \& Júnior, P. R. S. (2004). Pesquisa de conhecimento, atitudes e práticas na população brasileira de 15 a 54 anos. Boletim Epidemiológico AIDS/HIV, 1 (1), 18-24. Recuperado de http://www.aids.gov .br/final/dados/BOLETIM2.pdf

Waystaff, D. A., Delameth, J. D., \& Havens, K. K. (1999). Subsequent infection among adolescent African-American males attending a sexually transmitted disease clinic. Journal of Adolescent Health, 25 (3), 217-226.

Whitehead, B. D. (2001). What's god got to do with teen pregnancy prevention? In B. D. Whitehead, B. L. Wilcox \& S. S. Rostosky (Eds.), Keeping the faith: The role of religion and faith communities in preventing teen pregnancy (pp. 9-30). Washington, DC: National Campaign to Prevent Teen Pregnancy.

Whitehead, B. D., Wilcox, B. L., \& Rostosky, S. S. (Eds.). (2001). Keeping the faith: The role of religion and faith communities in preventing teen pregnancy. Washington, DC: National Campaign to Prevent Teen Pregnancy.

Wilcox, B.L., Rostosky, S.S., Randall, B.A., \& Wright, M.L. C. (2001). Reasons for hope: A review of research on adolescent religiosity and sexual behavior. In B.D. Whitehead, B.L. Wilcox, \& S.S. Rostosky (Eds.), Keeping the faith: The role of religion and faith communities in preventing teen pregnancy (pp. 31- 83). Washington, DC: National Campaign to Prevent Teen Pregnancy.

Xavier, A. C. M. (2005). Comportamento sexual de risco na adolescência: Aspectos familiares associados. Dissertação de Mestrado inédita apresentada ao Programa de Pós-Gradua ção em Psicologia do Desenvolvimento, UFRGS. Porto Alegre

\section{Notes}

* Research article 